headsches, neuralgia, nasal-and naso-pharyngeal catarrhs, and depression both physical and metital. In a few instances only there were distinct evidences of declared gout-tophi in the ears, or joint affections.

One of the difficulties in arriving at a correct estimate of the value of any system of diet in the treatment of chronic disease is the fact that in nearly all cases the physiclan finds that 16 'Is essential in' the interest of the patient to have recourse to measures calculated to improve the functional activity of one or more of the tissues of the body, for example, the skin, bowelg, liver or other organs. This'difficulty is in private practice insurmountable, and therefore the conclusion one arrives at as to the part played' by diet in such cases can only be stated as a general impression.

The method followed in my observations has been brlefly as follows: Ten of the cases in this - series of varying grates of severity' were put on a purin-free dlet, which waintained for periods ranging from a few weeks to ovter ten months; in the remainder the amount of purins in the diet was'notably reduced, but not out of proportion to the reduction in the total amounts of nittrogenous foodstuffe. In many instances daily observations were made for short periods on the urinary puring, which were estimated by the purinometer.

Accessory meastures of treatment were relatively : as much employed in the purin-free-fed subjects as in those in which less ${ }^{2}$ ttention was directed to the purin content of the food. I have made a carefal comparison bf the result of treatiment of these esses, and found that the rate of recbvery and the proportion of cases of apparent complete recovery is no higher in the patients fed on a purinTree diet than in those in which the parins are less restricted. As a matter of fact the orily instances in which the treatment employed was entirely unsuccessful were those of two patients in the purin free group. Both of these were severe cases of paroxysmal headache: one being specially noteworthy. This patient had suffered from extremely severe headaches of aparoxysmal character fot' over twenty'five years. She had consulted numerous 'physiclens 'in different' parts, and tried many systems of treatment, both dietetic and medicinal, without materia imptovement. As' she had never trled a purin-free dietary, the case seemed to be a suitable one for this régime. Alter ten morths of this dietary the patient writes stating that her condition is practically no better, the severity of the headaches' being unabated.

The conclusion I hive come to from practical experience of this strbject Is that there is no special therapeutic effect in a purin-free diet. The benefit that is derived from such a régime in certain cases would, I believe, be equally attained by the uge of a carefully-planned system of feeding framed without special reference to purin contents. In some cases the restriction in amount of anima protein lood is of special value, in others the diminution in the crobolity drate, and especially the sugars, is equally efficaciouts; and'in others the restriction of varlous alcoholic liquors will suffee.

The polnts which should guide us in framing the dietary can only be laid down atter consideration of all the avall able clinical facts in each case. I frequently find that the dletary of the patients who consult me needs no modification whitever, experience having tanght the pattent the value of a diet in which the amount of nitrogenous foodtuffs, purins, or carbohydrates is not apparently in any way excessive. Complete relief from their gouty gymptoms is attained in suth eases by measures directed to increase the functional activity of the liver, kidneys; skin, or thy roid gland.

The teachitng of clinical experfences is therefore in perfect harmony with the teiching of the laboratory In showing that in gout it is not so much a distarbance of purin metabolism ts a perverted function of one or more organs of the boty which is of pathogenic'moment.

REFERENCE.
1 Lancet, 1905.

UNDER the will of the late Mr. William Lyon, of Wanstead, who died on October 4th, Saffron Walden Hospital receives a sum: of $\$ 500$

THE late:Mr. Thomas Berry, of Manchester and Chester who died on August 31st, left $£ 1,000$ each to the Glinical Hospital for Women and Children, Manchester; the Altrincham Provident Dispensary and Hospital ; Salford Royal Hospital ; and the Ancoats Hospital and Dispensary.

\section{A CLINICAL LECTURE ON}

A CASE OF GEREBRAL TUMOUR ABSOCIATED WITH SUBJECTIVE SENSATIONS OF SMELL.

Delivered at Middersex Fospital.

BY H. CAMPBELL"THOMSON, M.D., E.R.C.P., PHYSICIAN TO OUT-PATIENTS AT MIDDLESEX HOSPITAL; PHYSICIAN TO THE HOSPITAL FOR EPILEPSY AÑ PARAÍYSIS, MAIDA VALE.

Gentilemen, -The patient of whom I wish to speak to-day is a woman of 33 years of age. She first-complained of her eyesight, and on this account she went to the Weatern Ophthalmic Hospital. There it was difcovered that the was-suffering from' a slight degree of weakness of the'left external rectus muscle and from double optic neturitis b: conslderable intengity, though her power of vision was still fairly good.*

The fact that the eyesight was the earliest symptom of which this patient complained must not lead you to think that optic neuritis is, at any rate in its earlier stages, necessarily associated with failure of vision. It is, indeed, common to find patients iwith advanced degrees of optic neuritis who have no idea that their vision is impaired, and hence' it 'is' necessary in -every case where there is a probability of the occurrence of neurltis to make a routine practice of using the ophthalmoscope.

After the discovery of the ocular signs I was asked to see the patient, and some of you here may remember her coming up to one of my weekly demonstrations "on nervous diseases. Later on she was admitted under my care into the Hospital for Epllepsy and Paralysis, Maida Vale.

Further examination showed that, in addition to the optic neuritis, headache,"naurea, and a subnormal temperature were present; all of which are "general " signs of a cerebral tumour; but the pufse-rate," which is often slow, was in this instance about normal. These ygyptoms, then, taken together justified a diagnosis of cerebral tumour; and the next step, therefore; was to try to determine its pasition. Now, the power of locallzing intracranial tumours depends upon our knowledge of the disturbance of ' function of that area of the brain in which the tumour happens to be situated; hence it' is posiftble to localize tumours accurately only when there is a alsturbance of those parts of the brain the fanction of ${ }^{2}$ whlich is known, and growths in other parts, the soresilted "silent areas," often give no indications by which their localities can be defined.

But even" when "localizing" symptoms are obtained our difficulties are by no means at an end, for it is still necessary to conslder whether such signs ind icate the primary seat of the growth, or whether they are the results of pressure from a distance, or of secondary changes; stoch as hydrocephalus, meningitis, and metsistatic deposits in parts of the brain which may be some distance from the position of the primary growth.

There must, of course, ofter be a good deal of difficulty In arriving at a satfofactory solution of this problem; but, broadly speaking, the earlier the locallzing symptoms appear, the more value can'be attached to them as -indicators of the site of the tumour. In the case now under consideration there was throughout only one localizing sign of importance, nsmely, a sensation of smell. "Thi's gensation of smell, which was dilways of a disagreesble nature, and which oceurred with great frequency; was regarded as the key to the position of the tumour.

Many years ago Dr. Hubhlings Fackson trew the attention of meurologiets in this country to the occurremce of a group of epileptics who stiffered from tor ude 'senstitions' of smell, which were tiften accompanied by "dreamy reminiscences," and a matleatory'movement of the lips, tongue, and faw, 'and placed" the probable seat of the infilal "discharte in ruch cases' in the region of the uncinate convolution in accordance with the physiological localization of mell and taste as determined by Ferrier and others.

The accurac of this localizdtion has since been abnndantly proved by records of tamours of the anterfor' part of the temporo-sphenoidal tobe, though trumours in this

* I am indebted to.Mr. George Thompson for a nnte of the obserta ons made at the Western Ophthalmic Hospital. 
situation are of course by no means commonly met with.

Dr. Hughllings Jackson has himself recorded such cases, and more recently some interesting examples were published in a lecture by Dr. Thomas Buzzard.

I myself have met with one other case, a note of which is recorded in an article on subjectlve sensations of epilepsy in the Practitioner, 1897. The patient was an inmate of King's Ward under the care of Dr. J. Klngston Fowler, and suffered from cerebral abscess, with whlch were associated frequent epileptiform attscks that. were preceded by a sensation of an unpleasant smell. After death a large abscess was lound in the fore part of the temporo-sphenoidal lobe. Another interestlng feature of this case was the presence of excessive hunger and thirst, sensations which appear to be more intimately connected with leslons in the vicinity of the temporo.sphenoidal lobe than with those of other parts of the brain.

Thus, in our case of to-day, the' frequent repetition of the sensations of smell justified the assumption that the tumour was seated in the region of the uncinate gyrusthat 1s, at the anterior extremity of the temporosphenoidal lobe.

The next step was to try to decide on which side of the brain the tumour was sltuated, and evidence on this point was far from being conclusive. At first there were only two points. whlch gave any assistance-namely, the weakness of the external rectus on the left side, and signs that the optic neurltis was more advanced also on that side.

The weakness of the left external rectus was very slight and seemed tó pass off entirely later on, but, so far as it went, it was an indlcation of distarbance in the conductivity of one sixth nerve, which would naturally be most likely to take place on the same side as the.tumour the sixth nerve, however, from its long straight course is a sensitive indicator of any disease which causes displacement of or pressure upon the structures at the base of the brain, and for thils reason too much weight must not be given to slight disturbance of its functions for purposes of localization. The second plece of evidence, that derlved from a comparison between the degree of optic neuritis in the two eyes, was in keeping with the suggestion afforded by the weakness of the external rectus, for the neuritis appeared to be of longer standing in the leit eye, and statistics show that on the whole neuritis is more likely to appear first on the same side as the tumour. No doubt there are many exceptions to this rule, but, as Sir Victor Horsley has shown, some of them are probably more apparent than real, and depend upon the interpre. tation that has been placed on the condition of the neuritis by the observer, for the polnt to determine is not on which side the neuritis is most intense at any given time, but on which side the neuritis is of longest standing, which two conditions by no means necesearily correspond.

sdded to these two signs there occurred later in the course of the malady a third-namely, twitchings of the masseter muscle on the right side.

This later sign was capable of being interpreted in two ways. It might have been that the peripheral nerves at the base of the brain were belng irritated, or, on the other hand, It might be that the twitching was due to irritation of the motor area of the cortex on the opposite side.

Acceptance of the first explanation would entail the presumption that the tumour was situated on the right side, and would therefore be antagonlatic to the conclusions based upon the weakness of the sixth nerve and the unequal duration of the neuritis which we have already discussed, whereas adoption of the second hypothesis-namely, that the twitching was due to cortical irritation-would be an additional support to the view that the tumour was, on the left side. A careful search failed to, reveal any signs of irritation or pressure upon peripheral nerves, and it seemed most reasonable to take the view that the twitching was of cortical origin, and that this might happen is not surprising when we consider the contiguity of the fore part of the temporo sphenoldal lobe to the motor ares for the face. While mentioning these relations it may be stated that at no time was there any sign of difficulty in speech such as would have suggested an extension of the disease into Broca's convolution.

The next point was to consider the probable nature of the tumour-always a most difficult problem, and ore which frequently has to remsin uniolved,
In this Instance there was no reason for suspecting the presence of syphilis or tubercle, and, moreover, large doses of iodide of potassium falled to give any relief. It is, however, necessary to bear In mind that large gummata by no means always react readily to trealment by mercury and iodides, and instances in which growths persist in spite of the administration of these drugs are not infrequent. It is also equally necessary to remember that the cases in which improvement follows antispecific remedic $s$ are not all of syphilitic nature, for iodides and mercury are capable of modifying - at any rate, for a time-the growth of other varlettes of tumours. On the whole, it seemed most likely that the growth would prove to be of a gliomatous or sarcomatous nature.

A thorough trial of the effects of potassinm lodide having been given and no definite results having been obtained, it became evident that further steps would have to be taken to preserve the eyesight, for the fields of vision, on which a carefal watch had been kept by Mr. Mayou, were now becoming contracted, and there was imminent danger of the neuritls belng succeeded by atrophy.

The position of affalrs was fully explained to the patient, who suffered so little from the general effects of the tumour that she found it somewhat difficult to understand the necessity for an operation to preserve the eyesight, which, to her mind, was still fairly good. It was, however, finally decided that an operation should be perforned, with the general understanding that it was to be looked upon primarily as a means of preserving vision, and that if the tumour was not obvious and readily removable, no efforts which would be likely to endanger life should be made to search the brain tissue for it, for the patient felt that her general condition was not bad enough to lead her to take any more rlsk than was necessary for the object of preserving sight.

Mr. Lenthal Cheatle accordingly trephined the skull, incised the dura mater, and exposed the anterior part of the left temporo-sphenoldal lobe. As is usual, the operation was performed in two stages, with an interval of a week between them. No tumour was visible on the outer surface, and a briel examination of the parts around, such only as was justlfied by the patient's request, failed to reveal any growth. The tension under which the intracranial structures had previously been labouring was shown by the bulging of the brain substance which immediately occurred.

The patient quickly recovered from the effects of the operation, and it was gratifying to find that the object for which it was performed was soon attuined, for the neuritls gradually eubsided and in a few weeks the discs showed only an insignificant trace of thelr recent infiltration. The tumour, of course, was there as belore, and one could only hope that the symptoms might subside as sometimes happens. For a while it seemed as if this hope might be realized, for during the first six months following the operation the symptoms showed no signs whatever of increasing and at times scarcely troubled the patient at all, but at about the time of writing the patient has become worse again and signs have appeared whlch can only mean that the effects of the growth are widely and rapidly spreading.

With this termination it may be asked whether it was worth while to operate on the patient, and to this question I am sure every one who saw the case will unhesitatingly give an affirmative answer. The operation in itself was not one attended by danger, and the relief of intracranial pressure which was obtained undoubtedly saved the patient's sight and also almost certainly postponed the onset of the more severe symptoms. Added to these benefits there was the hope, unhappily in this case not realized, that a tumour might have been found and removed.

This case affords a good example of the manner in which neuritis of the optic nerve subsides after the pressure has been relieved by trephining the skull and inclsing the dura mater, and at the preaent time there is in Bird Ward a patient, a child, with signs of cerebellar tumour, whom Mr.John Murray has trephined with equally satisfactory results.:

This important matter of preserving the sight must always be kept in mind or you will meet with cases of tumour like one whom you may see attending my outpatient department, who refused to entertaln the idea of operation, both in this hospltal and elsewhere, with the 
result that he is now completely blind, though the other eymptoms are by no means severe, and have in no wise progressed during the past eighteen months. Had he consented to have been trephined we can say with reasonable certalnty that he would have been able to see quite well to-day.

After a fair trial of medicinal treatment the question of operation should be discussed, and its objects may conveniently be divided into two groups, namely (1) to preserve the sight, and (2) to remove the tumour. There are but few cases in which it is unreasonable to operate for the preservation of sight, but careful thought is necessary before an attempt is made to remove the tumour.

Consideration of the cases in which it is desirable to attempt to remove the tumour is, however, a large subject, and one which must be postponed for discussion on a future occasion.

\section{Ant Adurrss}

ON

\section{MEDICAL PRACTITIONERS AND PUBLIC HEALTH.}

Delivered Before the Walthamstow Division of the British Mhdical association.

BY TREVOR FOWLER, L.R.C.P., L.R.C.S.I., D.P.H.CАMB.,

M.O.H. EPPING; CHAIRMAN OF THE DIVISION.

As a medical officer of health I am asked not infrequently to advise my brother medical practitioners in matters connected with public health, not so much in questions of diagnosis, and in the steps required for the prevention of disease-in neither of which do I claim any epecial knowledge-but more particularly in reference to the duties of the medical attendant under the numerous Sanitary Acte, Local Government Orders, etc., in which these duties are specified. I must say that I have many times been surprised to find how little the medical practi. tioner reallzes the position in which the Leglslature has placed him, and how apparently indifferent he is to this aspect of the question. Yet both morally and leglslatively hls relationship to the prevention of disease has always been very real and important.

Previous to the passing of the first Public Health Act in 1848, very little had been done by the Logislatare in regard to sanitation; and although that Act showed an awakening of the public conscience to the fact that "a nation's health is a nation's wealth," it was not until the passing of the Pablic Health Act of 1875 that effectual measures for the prevention and against the spread of disease became law.

During the interval between the passing of these two Acts the growth of knowledge as to the origin and spread of infectious diseages was remarkable. Men of sclence had worked out and settled bey ond dispute new problems, old theorles had to be abandoned, and the subject of public health had assumed a position not only of national but of universal importance. $A s$ in all new movements, the earlier advocates of the science of hygiene, and the application of its discoveries to public uses, had much opposition to contend with-opposition not merely from Ignorant and illiterate persons, bat also from others of intelligence, whose motives were only too plainly personsl and interested. Numerous Instances of such opposition might be produced. Among others, I can recall the case of a medical practitioner who, because he dared to assert that a typhold fever outbreak was due to contaminated wells in his district, was subjected to the grossest Indignities; he was publicly burnt in effigy, and on one occasion in the dusk of evening he had an open coffin placed across his door in the diabolical hope that he might fall into 1t; and at another time this came man was bitterly ridiculed when he asserted that an outbreak of Asiatic cholera in a famlly he had been called to attend was due to contamination of the drinking water, an assertion afterwards proved to be correct by an examination of the house drains, coupled with the history of the first case in the house. This occurred so far back as the year 1865. Again, I have known the case of a medical practitioner who, having previously enjoyed the good will and esteem of his neighbours, had to endure intense hostility and bitterness when he bad succes sfully carrled through, in the face of determined opposition, a scheme for sinking a deep well to supply water in substitution for that of the polluted wells of the village in which he resided. It is within my knowledge, also, that besides the worrles and annoyances which both of these men had to endure, they suffered very serious pecuniary loss in their practices as well.

All this, however, is now past history, and to come down more to the present day, let us consider how the medical practitioner stands as regards what is expected and sometimes requlred of him by the Legislature. Where the duties are optlonal and no provision is made for remuneration, no blame can attach to any medical practitioner who ignores them, as nearly all do; but where statatory duties are accompanled by a fee, slthough he may think the sum inadequate he is bound to comply with the law.

To take first of all the Public Health Act of 1875 : under the regulations as to streets and houses, under Section 46, any two medical practitloners can give a certificate for the cleansing, whitewashing, or purifying of houses in a filthy or unwholesome condition affecting or endangering the health of any person, upon whlch the local authority is bound to act should the conditions appear to require it. I have never known an instance in which action bas been taken under this section.

Under the provisions against infection, Section 120 of the same Act, upon the certificate of any legally qualified medical practitioner that the cleansing and disinfecting of any house or part thereof, and of any articles thereln likely to retain infection, would tend to prevent or check infectious disease, it is the duty of the local authority to reguire the owner or occupier to cleanse and disinfect within a specified time. With regard to whose duty it is to carry out the cleansing and disinfecting, there is much misconception both on the part of the medical profeseion and the public; nsually it appears to be thonght by both. that it falls upon the local authority, whereas the section makes it quite clesr that the duty belongs to the owner or occupier, except where from poverty or otherwise the local authority may be of oplnion that the owner or occupier is unable effectually to do it.

In cases in which it is desirable that infected persons without proper lodging or accommodation should be removed to a hospital provlded for the purpose, the local authority may, on the certlficate of a medical practitioner, by order of any justice, have removed to such hospitil the infected person, or any person so sufferlng in a common lodging house may on a like certificate be removed by the local authority, and any person wilfully disobeying or obstructing "the execution of the order is liable to a penalty not exceeding £l0. The same section (124) includes persons on board any ship or vessel. It would be well if medical practitioners would always remember to warn infectious patients, and those in charge of them, of the penalties to which they are rendered liable in exposing themselves in streets, public places, shops, inns, or public conveyances. I am afraid it not infrequently happens that a doctor is called In to visit a patient, it may be a visitor, or a servant at another person's house, whom he finds suffering from a dangerous infectious disesse, and at once advises the patlent to be sent home, and this without any reference as to how the removal is to be effected, or what may happen if Section 126 of the Public Health Act is dlsregarded.

Under Section 142 any medical practltloner can give a certificate for removal to a mortuary-if such has been provided by the local authority-of the body of any one who has died of any infections disease, or any dead body In such a state as to endanger the health of the inmates, and the local authority may direct the same to be burled within a time to be limited in such order.

The Infections Disease (Prevention) Act, 1890 (Bections $5,15,17)$, also entitles the medical practitioner to give a certificate for the cleansing and disinfecting of any house or articles thereln likely to retain infection, and further allows that his certificate, stating that such disinfection and cleansing has been done to his satisfaction, may be accepted by the local authority.

Probably the Infectious Dlsease (Notification) Act, 1889, is one of the sanitary statutes with which the medical 